JURNAL EKONOMI

EFEKTIF
ISSN : $2622-8882$, E-ISSN : 2622-9935

Jurnal Ekonomi Efektif, Vol. 2, No. 1, Oktober 2019

(a) Prodi Manajemen Fakultas Ekonomi Universitas

Pamulang

\title{
PERAN KOMITMEN ORGANISASI DALAM PENGARUH NEGATIF TURNOVER INTENTION TERHADAP LOYALITAS KARYAWAN (Studi Kasus di Universitas Pamulang)
}

\author{
Ajimat \\ math.unpam@gmail.com
}

\begin{abstract}
ABSTRAK
Loyalitas karyawan dalam sebuah perguruan tinggi (PT) merupakan salah satu faktor yang paling penting sebagai upaya untuk memperkuat kinerja organisasi tersebut. Sebagai upaya untuk menjaga kelancaran organisasi, salah satu upaya yang bisa dilakukan adalah mengatasi pengaruh negatif tingginya turnover intention yang dilakukan oleh karyawan. Penelitian ini secara khsusus bertujuan untuk menganalsis pengaruh turnover intention terhadap loyalitas karyawan dengan komitmen organisasi sebagai variabel moderator. Penelitian ini menggunakan metode penelitian kuantitatif dengan sampel sebanyak 61 karyawan yang diambil dengan menggunakan teknik proportionate stratified random sampling. Data diambil dengan menggunakan kuesioner terbuka yang dianalisis dengan menggunakan Structural Equation Modelling dan regresi linier. Hasil penelitian menunjukkan bahwa komitmen organisasi memiliki pengaruh yang signifikan sebagai variabel yang mempengaruhi hubungan turnover intention dengan loyalitas karyawan. Sebagai upaya untuk menurunkan pengaruh negatif turnover intention maka perlu adanya komitmen organisasi untuk meningkatkan loyalitas karyawan sebagai upaya menurunkan pengaruh negatif turnover intention karyawan.
\end{abstract}

Kata Kunci: Komitmen Organisasi, Turnover intention, Perguruan Tinggi, Loyalitas Karyawan, dan Structural Equation Modelling

\section{ABSTRACT}

Employee loyalty in a college (PT) is one of the most important factors as an effort to strengthen the performance of the organization. In an effort to maintain the smooth running of the organization, one of the efforts that can be done is to overcome the negative influence of the high turnover intention carried out by employees. This study specifically aims to analyze the effect of turnover intention on employee loyalty with organizational commitment as a moderator variable. The research method used is quantitative and uses a sample of 61 employees taken using the proportionate stratified random sampling technique. Data was taken using an open questionnaire which was analyzed using Structural Equation Modelling and linier regression. The results showed that organizational commitment has a significant influence as a variable that affects relationships, turnover intentions with employee loyalty. In an effort to reduce the motivation of negative turnover intentions it is necessary to have an organizational commitment to increase employee loyalty as an effort to reduce employee turnover motivation. 
Keywords: Organizational Commitment, Turnover intention, Higher Education, Employee Loyalty, and Structural Equation Modelling

\section{PENDAHULUAN}

Universitas Pamulang merupakan salah satu Universitas swasta terbesar di Provinsi Jawa Barat. Jumlah mahasiswa hampir 80 ribu yang berasal dari berbagai kota di Indonesia. Sejak awal berdiri pada tahun 2001 sesuai dengan SK Menteri Pendidikan Nasional Republik Indonesia Nomor 136/D/O/2001 maka tidak mudah bagi Universitas Pamulang untuk bisa menjadi Universitas swasta terbesar di wilayah Jawa Barat. Perjalanan Universitas Pamulang untuk menjadi seperti sekarang ini bukanlah hal yang mudah, banyak sekali persaingan antara satu kampus dengan kampus yang lain, apalagi banyak Universitas yang berada di wilayah Kota Tangerang Selatan yang tidak lokasinya tidak jauh dari Universitas Pamulang.

Sebagai salah satu perguruan tinggi yang tentunya perlu memberikan pelayanan yang maksimal terhadap mahasiswa sehingga mahasiswa mendapatkan pelayanan yang maksimal dari karyawan. Sebagai tenaga kependidikan yang berada di lingkungan kampus, maka karyawan juga dituntut untuk loyal terhadap Universitas sehingga pelayanan terhadap mahasiswa dapat maksimal. Sebagai upaya untuk menjalankan organisasi dengan baik, maka diperlukan katyawan yang mampu bekerja secara maksimal dan mendukung organisasi tersebut. Salah satu hal yang menjadi permasalahan dari karyawan yang ada di Universitas Pamulang adalah tingginya turnover yang dilakukan oleh karyawan. Banyak karyawan yang keluar masuk dari perguruan tinggi tersebut. Penyebab utama dari adanya turnover di perguruan tinggi tersebut adalah sikap kurang loyal dari karyawan terhadap organisasi tersebut. Persaingan antar kampus untuk meningkatkan jumlah mahasiswa perlu diantisipasi oleh manajemen yang ada di Universitas Pamulang sehingga tidak banyak karyawan yang keluar masuk.

Penelitian terdahulu terkait dengan turnover telah banyak diteliti sebelumnya dan penelitian ini mencoba untuk melengkapi penelitian terdahulu dengan menggunakan objek kajian yang berbeda. Penelitian dari Sa'diyah (2017) menunjukkan bahwa Secara parsial variabel Turnover Intention berpengaruh positif dan signifikan terhadap variabel kinerja karyawan dan Turnover Intention variabel dapat secara langsung mempengaruhi kinerja karyawan dan efek tidak langsung melalui kepuasan kerja. Asmara (2017) melakukan kajian serupa dengan objek karyawan di rumah sakit bedah Surabaya. Hasil penelitian menunjukkan bahwa turnover intention berpengaruh terhadap kinerja karyawan. Fitri (2018) melakukan kajian dengan objek kinerja pegawai dinas Pendidikan DKI Jakarta. Hasil penelitian menunjukkan bahwa (1) turnover intention berpengaruh negatif langsung terhadap prestasi kerja; (2) ketidakhadiran berpengaruh langsung negatif terhadap kinerja pekerjaan; (3) intensi turnover memiliki efek langsung positif terhadap absensi. Kinerja pekerjaan dapat ditingkatkan melalui pengurangan intensi turnover dan absensi

Sebagai upaya untuk menurunkan tingkat turnover, maka perlu adanya komitmen organisasi untuk memberikan kenyamanan bagi karyawan sehingga mereka merasa nyaman bekerja di tempat tersebut. Studi terdahulu tentang pengaruh komitmen organisasi telah dilakukan oleh peneliti sebelumnya. Pane dan Fatmawati (2017) melakukan penelitian yang bertujuan untuk melihat pengaruh kimtmen organisasi terhadap kinerja karyawan badan pertahanan nasional kota Medan. Hasil penelitian menunjukkan bahwa variabel komitmen afektif, komitmen normatif dan komitmen berkelanjutan berpengaruh positif signifikan terhadap kinerja karyawan. Nurandini dan Lataruva (2014) melakukan kajian serupa dengan objek pegawai Perum Perumnas Jakarta. Hasil penelitian menunjukkan bahwa variabel komitmen afektif berpengaruh positif dan signifikan terhadap kinerja karyawan, variabel 
komitmen normatif berpengaruh positif dan signifikan terhadap kinerja karyawan, dan variabel komitmen kontinyu berpengaruh positif dan signifikan terhadap kinerja karyawan. Sutanto dan Ratna (2015) melakukan kajian serupa. Hasil penelitian menunjukkan bahwa komitmen organisasi mempengaruhi kinerja karyawan. Karakteristik individu menyebabkan perbedaan dalam kinerja karyawan adalah status perkawinan, sedangkan jenis kelamin, usia, dan pengalaman kerja tidak menyebabkan perbedaan dalam komitmen organisasi.Hasil peenlitian dari Muhtarim dkk (2017) menunjukkan bahwa variabel kepuasan kerja berpengaruh negatif dan signifikan terhadap variabel turnover intention dan komitmen organisasi berpengaruh positif yang lemah terhadap turnover intention. Fadzillah dan Martono (2016) melakukan kajian yang menunjukkan bahwa semakin tinggi ketidakaman kerja akan meningkatkan keinginan berpindah dan semakin tinggi komitmen serta kepercayaan organisasional akan menurunkan keinginan berpindah. Setiyanto dan Hidayato (2017) melakukan penelitian yang menunjukkan bahwa kepuasan kerja tidak berpengaruh secara signifikan terhadap turnover intention namun komitmen organisasi berpengaruh signifikan terhadap turnover intention. Soedarmadi dkk (2017) melakukan kajian yang menunjukkan bahwa ketidakamanan kerja berpengaruh negatif signifikan terhadap intensi turnover, komitmen organisasi berpengaruh negatif signifikan terhadap intensi turnover, intensi turnover berpengaruh negatif signifikan terhadap kinerja karyawan. Penelitian serupa juga dilakukan oleh Susanti dan Palupiningdyah (2016). Hasil penelitian menunjukkan bahwa kepuasan kerja dan komitmen organisasi berpengaruh negatif dan signifikan terhadap turnover intention, kepuasan kerja dan komitmen organisasi berpengaruh postif dan signifikan terhadap kinerja karyawan, turnover intention berpengaruh negatif dan signifikan terhadap kinerja karyawan, dan turnover intention mampu memediasi hubungan kepuasan kerja dan komitmen organisasi terhadap kinerja karyawan.

Andriyadi dkk (2018) melakukan terobosan dengan menambahkan variabel intervening pada penelitiannya. Ia melakukan kajian tentang Peran Komitmen Organisasi dalam Menurunkan Pengaruh Negatif Turnover Intention terhadap Kinerja Karyawan (Studi kasus: GroupM Indonesia). Hasil penelitian ini menunjukkan bahwa turnover intention memiliki arah hubungan negatif terhadap kinerja karyawan dan komitmen meskipun tidak signifikan. Penelitian ini menjadi inspirasi dalam penelitian ini dengan menggunakan objek kajian yang berbeda serta variabel yang berbeda. Penelitian ini akan mengupas peran komitmen organisasi sebagai variabel intervening dan loyalitas karyawan sebagai variavel terikat. Urgensi dari penelitian ini sebagai upaya untuk melihat peran komitmen organisasi terhadap turnover karyawan yang ada di Universitas Pamulang.

Berdasarkan uraian diatas, model penelitian seperti pada gambar 1, dan pengembangan hipotesis sebagai berikut:

H1: Terdapat pengaruh antara turnover intention terhadap loyalitas karyawan

$\mathrm{H} 2$ : Terdapat pengaruh antara komitmen organisasi terhadap loyalitas karyawan

H3: Komitmen organisasi memoderasi turnover intention terhadap loyalitas karyawan
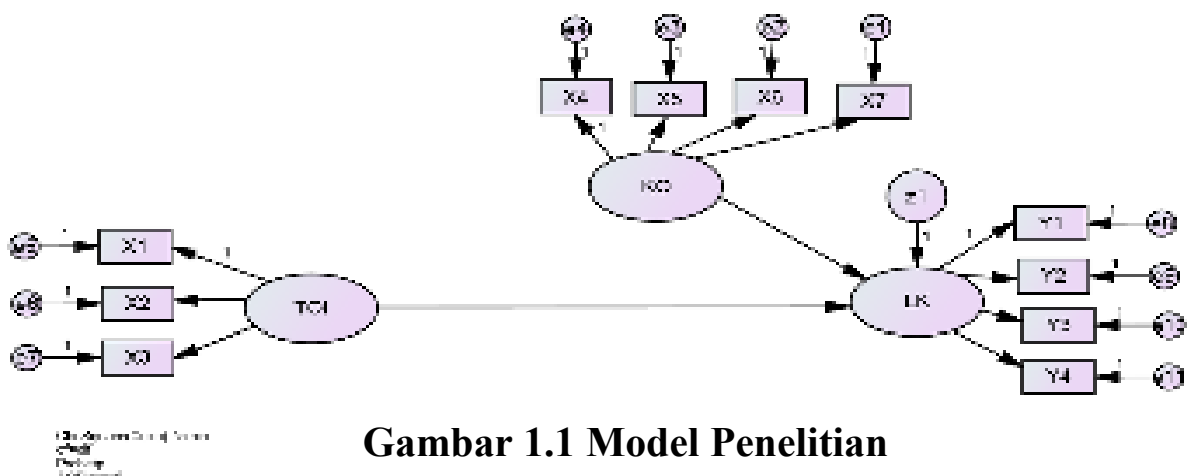


\section{METODE}

Penelitian ini menggunakan metode penelitian kuantitatif. Hasil olah data akan dideskripikan secara jelas sehingga mampu menjawab permasalahan yang diajukan dalam penelitian. Data pada penelitian ini dikumpulkan secara langsung dari lapangan melalui kuesioner terbuka yang disusun terstruktur. Adapun data yang digunakan merupakan data primer yang diberikan kepada responden dan data sekunder diperoleh melalui kajian pustaka dan data dari organisasi yang sudah ada.

Populasi merupakan sekumpulan objek yang menjadi pusat penelitian. Populasi dalam penelitian ini adalah seluruh karyawan Universitas Pamulang. Jumlah sampel yang digunakan dalam penelitian ini sebanyak 61 karyawan. Penarikan sampel dalam penelitian ini menggunakan teknik probability sampling dengan metode proportionate stratified random sampling, yaitu teknik yang digunakan bila populasi mempunyai anggota atau unsur yang tidak homogen dan berstrata secara proporsional (Sugiyono, 2010). Sebagai upaya untuk menganalisis data, maka metode statistik deskriptif digunakan untuk menggambarkan data yang terkumpul sebagaimana adanya. Adapun metode berikutnya dengan menggunakan Structural Equation Modelling dan regresi linier. Adapun metode tersebut adalah metode statistika untuk menilai suatu model dengan melihat adanya hubungan sebab akibat antar variabel yang diteliti.

\section{PEMBAHASAN}

Penelitian ini untuk mengukur kontribusi turnover intention terhadap loyalitas karyawan dengan mempertimbangkan komitmen organisasi sebagai variabel moderating dengan menggunakan persepsi responden melalui kuesioner. Responden memberikan nilai terhadap kuesioner tertutup dengan pilihan skala likert $1-5$.

Jumlah responden dalam penelitian ini sebanyak 61 karyawan. Dengan deskripsi sebagai berikut:

Tabel 1. Deskripsi Responden

\begin{tabular}{|l|l|l|r|}
\hline \multicolumn{2}{|c|}{ Profil } & \multicolumn{1}{c|}{ Jumlah } & Persentase \\
\hline \multirow{4}{*}{ Jenis Kelamin } & Pria & 25 & $40,98 \%$ \\
\cline { 2 - 4 } & Wanita & 36 & $59,02 \%$ \\
\hline \multirow{5}{*}{ Masa Kerja } & $<1$ th & 5 & $8,20 \%$ \\
\cline { 2 - 4 } & $1-5$ th & 32 & $52,46 \%$ \\
\cline { 2 - 4 } & $>5$ th & 24 & $39,34 \%$ \\
\hline & SMP & 8 & $13,11 \%$ \\
\cline { 2 - 4 } & SMA & 12 & $19,67 \%$ \\
\cline { 2 - 4 } & D3 & 24 & $39,34 \%$ \\
\cline { 2 - 4 } & S1 & 15 & $24,59 \%$ \\
\cline { 2 - 4 } & S2 & 2 & $3,28 \%$ \\
\hline
\end{tabular}

Perhitungan menggunakan SPSS 23 dan SPSS Amos 23. Hasil penelitian tidak dapat ditunjukan tidak dengan bentuk diagram tetapi output text sebagai berikut:

Tabel 2. Uji validitas dan reliabilitas instrumen

\section{Case Processing Summary}

\begin{tabular}{|cl|r|r|}
\hline & & $\mathrm{N}$ & \multicolumn{1}{c|}{$\%$} \\
\hline Cases & Valid & 61 & 100,0 \\
& Excluded $^{\mathrm{a}}$ & 0 &, 0 \\
& Total & 61 & 100,0 \\
\hline
\end{tabular}

a. Listwise deletion based on all

variables in the procedure. 


\begin{tabular}{|} 
Reliability Statistics \\
\begin{tabular}{|r|c|}
\hline $\begin{array}{c}\text { Cronbach's } \\
\text { Alpha }\end{array}$ & N of Items \\
\hline, 883 & 11 \\
\hline
\end{tabular}
\end{tabular}

Berdasarkan tabel 2, dapat dikatakan bahwa instrumen secara keseluruhan valid dan reliabel dengan nilai cronbach's alpha lebih besar dari 0,6.

Tabel 3. Assessment of normality

\begin{tabular}{|l|rrrrrr|}
\hline Variable & min & max & skew & c.r. & kurtosis & c.r. \\
\hline Y1 & 2,000 & 5,000 &,- 594 & $-1,894$ & 1,012 & 1,614 \\
Y4 & 2,000 & 5,000 &,- 753 & $-2,400$ &, 530 &, 845 \\
Y3 & 2,000 & 5,000 &,- 729 & $-2,325$ &, 279 &, 445 \\
Y2 & 2,000 & 5,000 &,- 695 & $-2,217$ &, 211 &, 336 \\
X7 & 2,000 & 5,000 &,- 443 & $-1,411$ &,- 317 &,- 505 \\
X6 & 2,000 & 5,000 &,- 610 & $-1,944$ &, 207 &, 329 \\
X5 & 2,000 & 5,000 &,- 545 & $-1,737$ &, 118 &, 187 \\
X4 & 2,000 & 5,000 &,- 389 & $-1,241$ &,- 396 &,- 631 \\
X3 & 2,000 & 5,000 &,- 803 & $-2,560$ &, 877 & 1,398 \\
X2 & 2,000 & 5,000 &,- 309 &,- 986 &,- 657 & $-1,048$ \\
X1 & 2,000 & 5,000 &,- 604 & $-1,925$ &,- 236 &,- 376 \\
Multivariate & & & & & $-2,122$ &,- 490 \\
\hline
\end{tabular}

Tabel 3 merupakan uji normalitas menggunakan SPSS Amos 23, Nilai cr menunjukan 0,49 yang dapat diinterpretasikan sebagai penunjuk bahwa data berdistribusi normal karena nilai mutlak cr kurang dari 2,56.

Tabel 4. Model regresi I

Coefficients $^{\mathrm{a}}$

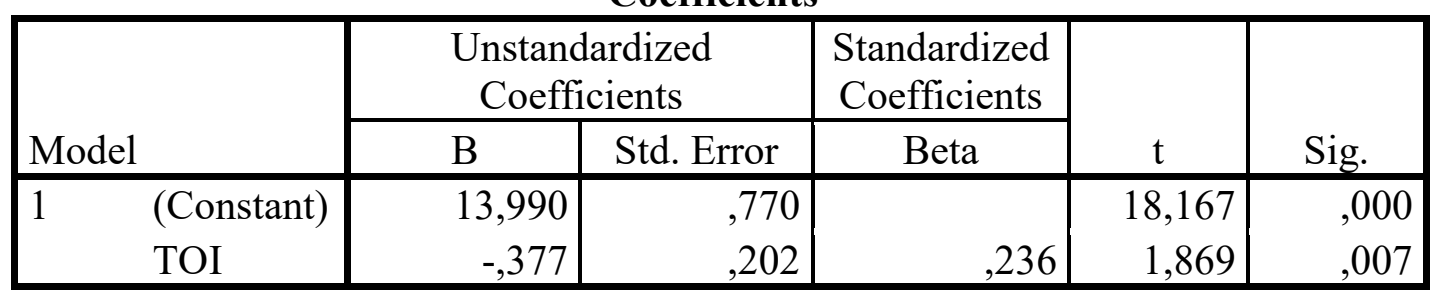

a. Dependent Variable: LK

Berdasarkan tabel 4 model regresi I, menunjukkan persamaan regresi $\mathrm{LK}=13,990$ 0,377TOI. Dengan melihat nilai sig. Yang lebih kecil dari 0,05 dan koefisien -0,377 berarti bahwa terdapat pengaruh yang negatif dan signifikan antara turnover intention dengan loyalitas karyawan. ditingkatkan atau dengan kata lain hipotesis pertama diterima.

Tabel 5. Model regresi 2

Coefficients $^{\text {a }}$

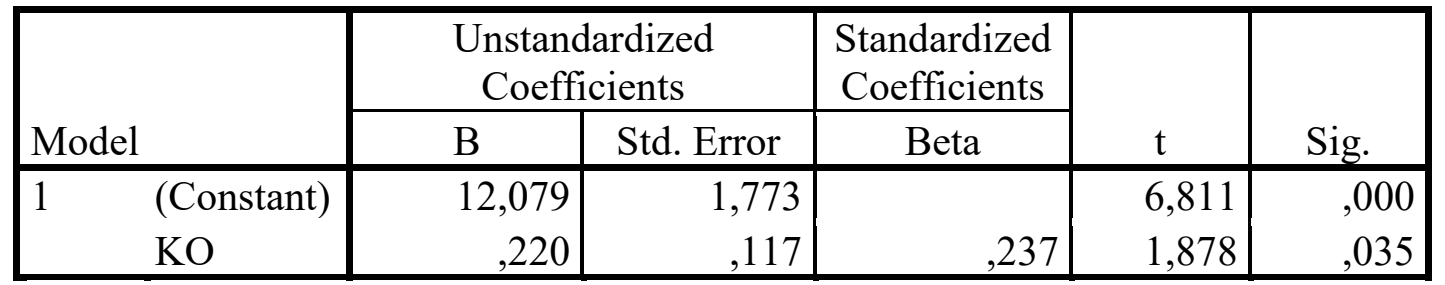

a. Dependent Variable: LK 
Tabel 5 model regresi 2 menunjukkan persamaan regresi $\mathrm{LK}=12,079+0,22 \mathrm{KO}$ dengan nilai sig. Yang lebih kecil dari 5\% yaitu 0,035. Hal ini memberikan arti bahwa hipotesis kedua diterima yakni terdapat pengaruh yang signifikan dan positif antara komitmen organisasi terhadap loyalitas karyawan.

Tabel 6. Model regresi 3

Model Summary

\begin{tabular}{|l|r|r|r|r|}
\hline Model & \multicolumn{1}{|c|}{$\mathrm{R}$} & R Square & $\begin{array}{c}\text { Adjusted R } \\
\text { Square }\end{array}$ & $\begin{array}{r}\text { Std. Error of } \\
\text { the Estimate }\end{array}$ \\
\hline 1 &, $673^{\mathrm{a}}$ &, 453 &, 381 & 1,32013 \\
\hline
\end{tabular}

a. Predictors: (Constant), TOI*KO, TOI, KO

\section{Coefficients $^{\mathrm{a}}$}

\begin{tabular}{|l|r|r|r|r|r|}
\hline \multirow{2}{*}{ Model } & \multicolumn{2}{|c|}{$\begin{array}{c}\text { Unstandardized } \\
\text { Coefficients }\end{array}$} & $\begin{array}{c}\text { Standardized } \\
\text { Coefficients }\end{array}$ & & \multirow{2}{*}{ t } \\
\cline { 2 - 4 } & \multicolumn{1}{|c|}{ B } & Std. Error & \multicolumn{1}{c|}{ Beta } & \multicolumn{1}{c|}{$\mathrm{t}$} \\
\hline 1 (Constant) & 13,423 & 1,877 & & 7,150 &, 000 \\
TOI &,- 278 &, 236 &, 174 & 13,179 &, 043 \\
KO &, 092 &, 195 &,- 100 & 10,473 &, 038 \\
TOI*KO &, 014 &, 008 &, 323 & 11,693 &, 026 \\
\hline
\end{tabular}

a. Dependent Variable: LK

Berdasarkan tabel 6, kita dapat melihat persamaan regresi berganda $\mathrm{LK}=13,423$ $0,278 \mathrm{TOI}+0,92 \mathrm{KO}+0,014 \mathrm{TOI} * \mathrm{KO}$ dengan nilai sig. berturut-turut 0,$43 ; 0,38 ; 0,26$ hal ini menunjukan hipotesis ketiga diterima bahwa komitmen organisasi memoderasi turnover intention terhadap loyalitas karyawan. Nilai Adjusted $\mathrm{R}$ menunjukan 0,381. Hal ini dapat diartikan bahwa kontribusi turnover intention dengan dimoderasi oleh komitmen organisasi berkontribusi sebesar 38,1\% terhadap loyalitas karyawan an sisanya dari faktor lain yang diluar penelitian.

\section{KESIMPULAN}

Berdasarkan hasil penelitian diatas dapat ditarik kesimpulan:

1. Terdapat pengaruh yang negatif dan signifikan antara turnover intention dengan loyalitas karyawan

2. terdapat pengaruh yang signifikan dan positif antara komitmen organisasi terhadap loyalitas karyawan

3. komitmen organisasi memoderasi turnover intention terhadap loyalitas karyawan

\section{SARAN FUTURE RESEARCH}

Dilihat dari kontribusi yang sebesar 38,1\% turnover intention yang dimoderasi komitmen organisasi terhadap loyalitas karyawan sisanya $61,9 \%$ merupakan kontribusi faktor lain diluar model penelitian, maka sebaiknya dilakukan penelitian lebih lanjut terkait faktor yang mempengaruhi loyalitas karyawan seperti budaya organisasi, kompensasi dan kepuasan kerja karyawan. 


\section{DAFTAR PUSTAKA}

Asmara (2017). "Pengaruh Turnover Intention terhadap Kinerja Karyawan di Rumah Sakit Bedah Surabaya". Jurnal Akuntansi dan Keuangan Indonesia, Volume 5 Nomor 2 JuliDesember 2017

Fadzilah dan Martono (2016). "Pengaruh Ketidakamanan Kerja, Komitmen Organisasional Dan Kepercayaan Organisasional Pada Keinginan Berpindah". Management Analysis Journal vol 5 (no 1) (2016) ISSN 2252-6552

Fitri. (2018). Pengaruh Intensi Turnover dan Ketidakhadiran Terhadap Kinerja Pegawai Dinas Pendidikan DKI Jakarta Vol 9 No 1 (2018): Jurnal Manajemen Pendidikan Volume 9 Nomor 1 Juli 2018

Muhtarim, dkk. (2017). Pengaruh Kepuasan Kerja dan Komitmen Organisasi Terhadap Turnover Intention Karyawan PT. XYZ. Jurnal Teknik Industri Vol. 5 No. 3 November 2017

Nurandini dan Laturava. (2014). "Analisis Pengaruh Komitmen Organisasi Terhadap Kinerja Karyawan (Studi Pada Pegawai Perum Perumnas Jakarta)". Jurnal Studi Manajemen \& Organisasi Vol 11, No 1 (2014) Juni 78 - 91

Pane dan Fatmawati. (2017). "Pengaruh Komitmen Organisasi Terhadap Kinerja Pegawai pada Badan Pertanahan Nasional Kota Medan”. Jurnal Riset Manajemen \& Bisnis (JRMB) Vol. 2. No.3. Oktober 2017

Sa'diyah dan Irawati. (2017). "Pengaruh Employee Retention dan Turnover Intention Terhadap Kinerja Karyawan Melalui Kepuasan Kerja pada Kospin Jasa Cabang Jawa Timur". Jurnal Kompetensi, Vol 11, No 1, April 2017

Setiyanto dan Hidayati. (2017)."Pengaruh Kepuasan Kerja dan Komitmen Organisasi terhadap Turnover Intention.”Jurnal Akuntansi, Ekonomi dan Manajemen Bisnis Vol. 5 No. 1, July 2017, 105-110 E-ISSN: 2548-9836

Soedarmadi, dkk. (2017). "Peran Keamanan Kerja dan Komitmen Organisasi Terhadap Turnover Intention Serta Dampaknya pada Kinerja Karyawan (Studi pada Karyawan PT. Indotirta Jaya Abadi Semarang - Aguaria). Jurnal Dinamika Sosial Budaya, Volume 19, Nomor 1, Juni 2017

Susanti dan Palupiningdyah. (2016). Pengaruh Kepuasan Kerja dan Komitmen Organisasi Terhadap Kinerja Karyawan dengan Turnover Intention Sebagai Variabel Intervening. Management Analysis Journal vol 5 (no 1) (2016)

Sutanto dan Ratn. (2015). "Pengaruh Komitmen Organisasional Terhadap Kinerja Karyawan Berdasarkan Karakteristik Individual.’Jurnal Bisnis dan Manajemen Vol.9, no. 1 Januari 2015 